\title{
Influence of the Shortening of the Winter Fertilization Prohibition Period in Hungary Assessed by Spatial Crop Simulation Analysis
}

\author{
Sándor Koós ${ }^{1}$, Béla Pirkó ${ }^{1, *}$, Gábor Szatmári ${ }^{1}{ }^{\circledR}$, Péter Csathó ${ }^{1}$, Marianna Magyar ${ }^{1}$, József Szabó ${ }^{1, \dagger}$, \\ Nándor Fodor ${ }^{2}$, László Pásztor ${ }^{1} \oplus$, Annamária Laborczi ${ }^{1}$, Klára Pokovai ${ }^{1}$ and Anita Szabó ${ }^{1}$ \\ 1 Institute for Soil Sciences and Agricultural Chemistry, Centre for Agricultural Research, \\ H-1022 Budapest, Hungary; koos@rissac.hu (S.K.); szatmari@rissac.hu (G.S.); csatho@rissac.hu (P.C.); \\ magyar.marianna@rissac.hu (M.M.); james@rissac.hu (J.S.); pasztor@rissac.hu (L.P.); laborczi@rissac.hu (A.L.); \\ pokovai.klara@atk.hu (K.P.); szabo.anita@atk.hu (A.S.) \\ 2 Agricultural Institute, Centre for Agricultural Research, H-2462 Martonvásár, Hungary; fodor.nandor@atk.hu \\ * Correspondence: pirko.bela@atk.hu \\ $+\quad$ This author died in 2020.
}

check for updates

Citation: Koós, S.; Pirkó, B.; Szatmári, G.; Csathó, P.; Magyar, M.; Szabót, J.; Fodor, N.; Pásztor, L.; Laborczi, A.; Pokovai, K.; et al. Influence of the Shortening of the Winter Fertilization Prohibition Period in Hungary Assessed by Spatial Crop Simulation Analysis. Sustainability 2021, 13, 417. https://doi.org/10.3390/su13010417

Received: 21 November 2020 Accepted: 27 December 2020 Published: 5 January 2021

Publisher's Note: MDPI stays neutral with regard to jurisdictional clai$\mathrm{ms}$ in published maps and institutional affiliations.

Copyright: (C) 2021 by the authors. Licensee MDPI, Basel, Switzerland. This article is an open access article distributed under the terms and conditions of the Creative Commons Attribution (CC BY) license (https:// creativecommons.org/licenses/by/ $4.0 /)$.

\begin{abstract}
The Nitrates Directive aims (a) to protect water quality across Europe from nitrates originating from agricultural sources that pollute ground and surface water, and (b) to promote good farming practices. One of the most controversial measures of the directive is the winter prohibition period of fertilization, which has been extended by a month in two steps in recent years. According to the regulation, it is forbidden to apply nitrogen fertilization in Hungary between 31st October and 15th February, even though the winter climate is gradually becoming milder. Using the fertilization data of nearly half a million parcels of land in the Hungarian Nitrate Database, a crop model-based spatial analysis was carried out. Our aim was to test if a shift in the prohibition period starting date from 31st October to 30th November caused any differences in the nitrate amount leached at a $90 \mathrm{~cm}$ depth. Detailed nitrate inputs and soil and weather databases were coupled with the $4 \mathrm{M}$ crop model. The yield, plant nitrogen uptake, and nitrate leaching under five major crops were simulated, covering a considerable portion of arable land. Shifting the prohibition period starting date did not result in significant changes in the nitrate leaching. Further runs of the $4 \mathrm{M}$ model with different weather scenarios are needed to decide whether the modification of the prohibition period significantly affects the amount of nitrate leached.
\end{abstract}

Keywords: nitrogen turnover; nitrate leaching; nitrate directive; prohibition period; digital soil maps; crop model; simulation

\section{Introduction}

Nitrogen is a vital nutrient for plant (animal and human) growth, but high concentration even in organic or inorganic forms cause risks to human health and the environment. In parallel, increasing agricultural production while reducing nitrogen $(\mathrm{N})$ losses is a major challenge for the European Union as well as producers worldwide [1,2]. This recognition led to the implementation of the Nitrates Directive in 1991 (91/676/EEC) as the first EU legislation regarding the agro-environment. The Nitrates Directive (1991) aims to protect water quality across Europe by preventing nitrates from agricultural sources polluting ground and surface waters and by promoting the use of good farming practices [3]. Its application in Hungary has been mandatory since 2002. However it has been in force for 30 years now, and several impact studies have come to the conclusion that the nitrogen pollution of ground water has not been significantly reduced. In addition, some measures have pointed to increasing trends in the EU [4-6].

From this perspective, Hungary is well-ranked, as its average livestock unit is around 22 heads per hundred hectares, which is 30\% under the EU average. In a review of the 
NP turnover of the EU countries, according to the Hungarian approach to estimating livestock units, around 75 livestock units (LU)/100 hectare agricultural land proved to be the optimum $[7,8]$. The livestock density in Hungary is only one third of the optimal number of 75 . In conjunction with this, the amount of $100-110 \mathrm{~kg} \mathrm{ha}^{-1} \mathrm{~N}$ (in active ingredients) applied as manure is far below the specific maximum limit of $170 \mathrm{~kg} \mathrm{ha}^{-1}$ ( $\mathrm{kg} \mathrm{ha}^{-1} \mathrm{yr}^{-1}$ of nitrogen from livestock manure) defined by the Nitrates Directive [9]. Besides this, the inorganic fertilizer consumption in Hungary is under the EU average, which is clearly visible from the cumulative nitrogen balances $[8,10,11]$. It can be concluded that the intensification of nutrient replenishment in the light of sustainable agriculture would increase crop production [12].

The requirements of good agricultural practices contain several issues regarding the deposition and use of nitrogenous fertilizers. In practical terms, one of the most problematic aspects is the winter prohibition period for applying fertilizers, which means that any nitrogenous fertilization is forbidden between 31st of October and 15th of February [13]. Before this regulation came into force, the beginning of the winter prohibition period was 1st of December. The matter of extending the winter prohibition period was discussed by the European Commission and the Hungarian government in two stages. Unfortunately, in the course of the negotiations the potential pollution effect of winter fertilization was never inspected, and attention was given only to the agro-political dimensions.

The regulations of the prohibition period in most European countries differ from the Hungarian ones. The Hungarian regulations treat the manure and slurry generated in animal husbandry and the fertilizers produced by industrial production in a uniform manner, and the use of all nitrogenous substances is prohibited between October 31 and February 15. Most European countries apply differentiated rules; they distinguish organic and inorganic nitrogenous substances and take into account the specificities of the crop grown when determining the length of the ban period [14].

Since the creation of the Nitrates Directive, compulsory data acquisition from farmers in Nitrate Vulnerable Zones (NVZs) has been in force [15]. Data regarding the livestock density, manure deposition, and applied amounts of organic manure and inorganic fertilizer should be clearly identified. As $67 \%$ of Hungary's arable lands are nitrate vulnerable, a database of hundreds of thousands of parcels has been established. In the beginning, the paper-based submission of the data made its management difficult. From 2015, only electronic submission has been accepted by the National Food Chain Safety Office (NFCSO), which has provided new opportunities for assessment. Given that the NVZs' data are assigned to Agricultural Parcel Identification System (MePAR) blocks, their use has enabled the compilation of a complex Geographic Information System (GIS) database. Until now compilation, scientific assessment, analysis, and evaluation have not been conducted.

The aim of this study was to compile a spatial GIS dataset based on compulsory data acquisition from farmers according to the Nitrates Directive, which can provide input data for the $4 \mathrm{M}$ model. The $4 \mathrm{M}$ process-based model is used for estimating the yield, crop $\mathrm{N}$ uptake, nutrient balances, and amount of $\mathrm{NO}_{3}-\mathrm{N}$ leached under the root zone in each MePAR block so that the values of these variables can be spatially visualized. Besides the currently valid fertilization prohibition period model, results for two shortened prohibition periods were simulated. The potential pollution effect of nitrate leaching on water quality was evaluated taking into account the reduced prohibition period. The aim of this study was to evaluate the effect of different timings of fertilization on nitrate leaching at the country scale. Evaluating the results of the $4 \mathrm{M}$ simulation model, we propose that the prohibition period could be shortened by 1 month without an increased risk of $\mathrm{N}$ leaching.

\section{Materials and Methods}

To ensure representativeness, it became necessary to interconnect some databases. 


\subsection{Agricultural Parcel Identification System (MePAR)}

An accurate definition of NVZs is given by Government Decree 27/2006. (II. 7.) [16] concerning the protection of waters against pollution caused by nitrates from agricultural sources. Inner city areas, large livestock farms and areas of manure storage are vulnerable to nitrates. In the case of farms, if the whole area is not vulnerable, data must be provided only for the NVZs. To identify NVZs, MePAR blocks are used, whereby a block ID allows the user to check if a given parcel is a NVZ [16,17].

Spatial data of MePAR blocks from 2016 were provided by the Government Office of Budapest, Department of Geodesy, Cartography and Remote Sensing (DGCRS). The original raster file was converted into vectors in order to facilitate the analysis.

\subsection{Hungarian Nitrate Database (HND)}

According to the Nitrates Directive, farmers who exercise agricultural activities (crop production or livestock farming on a scale that surpasses the needs of a single household) in a NVZ have to provide data [13]. The compulsory annual reports of the data and a logbook of the farm's management are processed by the NFCSO.

Recently, there have been two significant changes in the data report conditions, which allowed us to carry out our analysis.

Firstly, electronic submissions became available in 2015. This has dramatically increased the number of the submitted data sheets and also the size and representativeness of the areas concerned. Generally speaking, since 2016, data have been collected from the vast majority of NVZs; in some regions, almost $90 \%$ of the parcels are covered. Therefore building a unique GIS database became possible.

A second recent improvement was that cultivated crops and their average yields have to be indicated in the annual report. These two additional pieces of data have significantly increased the possibilities of data analysis. The use of nitrogen can be investigated not only from the perspective of nitrogen loads, but by calculating nutrient balances, the environmental impact associated with its use can also be quantified.

Moreover, simulation modeling of temporal and vertical changes in the soil mineral nitrogen content have become feasible. During the modeling work performed in the present research, cultivated crops and their yields were used mainly to calibrate the model and validate the results. Without model calibration and validation, the results cannot be regarded as valid.

\subsubsection{Data Collection and Filtering Procedure}

From the Hungarian Nitrate Database, the following data were used for the analysis for the year 2016:

- MePAR block identifier of the parcel;

- $\quad$ size of the fertilized area (ha);

- type of applied manure (liquid or solid manure), amount $\left(\mathrm{m}^{3} \mathrm{ha}^{-1}\right.$ or $\left.\mathrm{tha} \mathrm{h}^{-1}\right)$, application method, quantity of nitrogen applied in the form of manure $\left(\mathrm{kg} \mathrm{ha}^{-1}\right)$;

- quantity of applied nitrogen applied in the form of inorganic fertilizer $\left(\mathrm{kg} \mathrm{ha}^{-1}\right)$;

- $\quad$ crop and yield ( $\mathrm{t} \mathrm{ha}^{-1}$ ).

Raw data verifying and cleaning were conducted by the National Food Chain Safety Office and Institute for Soil Sciences and Agricultural Chemistry as data were received from farmers, without any checks during the data submission process. Two limit values were established regarding each data type. When the quantity of data exceeded the study level limit value, it was excluded from the present study. The analysis level was fixed to a relatively low maximum for the current analysis. Each piece of data located between the level of analysis and the study was examined on a case-by-case basis (Table 1). Explanations of the applied data filtering limits are given in the following section. The number of data included in the present study after applying the filtering process was 533,523. 
Table 1. Boundary limits of data filtering (first round).

\begin{tabular}{ccc}
\hline Data Type & Analysis Level & Study Level \\
\hline Maximum size of fertilized area (ha) & 250 & 350 \\
Amount of farmyard manure application $\left(\mathrm{t} \mathrm{ha}^{-1}\right)$ & 70 & 100 \\
Amount of slurry application $\left(\mathrm{m}^{3} \mathrm{ha}^{-1}\right)$ & 80 & 200 \\
N-content of mineral fertilizer $\left(\mathrm{kg} \mathrm{ha}^{-1}\right)$ & 200 & 300 \\
Yield $\left(\mathrm{t} \mathrm{ha}{ }^{-1}\right)$ & 1.5 & 15.0 \\
winter wheat & 1.2 & 12.0 \\
barley & 1.7 & 17.0 \\
maize & 0.5 & 5.0 \\
sunflower & 0.6 & 5.5 \\
rapeseed & &
\end{tabular}

\subsubsection{Data Filtering: The Maximum Size of the Fertilized Area}

For the first step, we sorted the extraordinarily high values. The most frequent inaccuracies were due to the use of the wrong unit or typing errors. We defined 350 ha (Table 1) as the largest size of a fertilized area, above which the data were not deemed to be valid. Bigger parcels were excluded from the analysis.

\subsubsection{Data Filtering of Manure and Mineral Fertilizer Application}

During the filtering process of manure and mineral fertilizer application data, some frequently observed errors in the database were typographical errors, using the wrong units, or not giving the amount of manure and/or fertilizer in tons per hectare $\left(\mathrm{t} \mathrm{ha}^{-1}\right)$, but rather, citing the amount of manure and/or mineral fertilizer in tons per parcel $\left(\mathrm{t}\right.$ parcel $\left.{ }^{-1}\right)$. To avoid such mistakes, the given amount of manure and/or mineral fertilizer in tons per parcel was divided by the size of the managed parcel (ha). If the result was in the formerly defined limits of realistic values regarding the whole territory, the value was corrected.

\subsubsection{Data Filtering of Yields}

Data filtering of yields were based on the ProPlanta (PP) system. PP is an environmentallyfriendly and cost-saving fertilizer recommendation system, developed at the Center for Agricultural Research and intended to support sustainable agriculture [18,19]. The maximal average yields of different crops defined in PP provide a basis for comparisons with farmers' data submissions. The most frequently encountered error regarding these data were the use of incorrect units and giving yields in quintal (q) instead of tons per hectare $\left(\mathrm{t} \mathrm{ha} \mathrm{a}^{-1}\right)$. To correct inaccurate yields, values given in quintal $(\mathrm{q})$ were converted into tons $(t)$. If the result obtained was in the formerly defined limits of realistic values regarding the whole territory of the farmer, the yield data was corrected; otherwise, it was excluded from the database (Table 1). The limits were 1.5-15.0 $\mathrm{t} \mathrm{ha}^{-1}$ for winter wheat, 1.2-12.0 $\mathrm{tha}^{-1}$ for barley, 1.7-17.0 tha ${ }^{-1}$ for maize, $0.5-5.0 \mathrm{t} \mathrm{ha}^{-1}$ for sunflower and 0.55-5.5 $\mathrm{t} \mathrm{ha}^{-1}$ for rapeseed. All yields below or above these values were disregarded.

After the first round of data filtering, the problem of having $0.0 \mathrm{tha}^{-1}$ yields occurred for a significant number of blocks. A possible explanation for this could be that at the time of submitting the annual report, yield data were not yet available to farmers.

\subsubsection{Spatial Identification of the Filtered Dataset}

In the filtered dataset comprising 533,523 records, the total area of the relevant parcels was 2,897,000 ha. The parcels are parts of 87,454 MePAR blocks; some such blocks contained only one parcel, while others contained more than 50.

To spatially identify the site of a parcel, the MePAR block IDs provided by DGCRS were used. We concluded that $10 \%$ of the data therein were incorrect, as farmers occasionally provided an incorrect MePAR block ID or simply did not notice that the former correct MePAR block ID had changed at the time of data submission in the financial year 
2015/2016. Incorrect data were excluded from our study, so the size of the studied area further decreased by 500,000 ha.

As there were, in extreme cases, 50 parcels within a MePAR block, we had to somehow manage the aggregation of these data. The crop grown on the largest area of a given block was considered. This led to a further decrease in area, because only the sowing area of the dominant crop was included in the analysis; areas dedicated to other crops were excluded. Extending the dominant crop to the whole MePAR block could lead to distorted sowing structure data, and averaging the fertilizer doses of the various crops within a MePAR block could give rise to significant systematic errors in the analysis.

After the aggregation and spatial assignment, the remaining area of the database was $1,562,000$ ha in 80,000 MePAR blocks, from which was possible to evaluate and spatially analyze the use of nitrogen.

For the crop production simulation with $4 \mathrm{M}$ [20], the remaining blocks were selected according to crop type. While $4 \mathrm{M}$ can handle various crops, $80 \%$ of arable lands in Hungary are dedicated to winter wheat, barley, maize, sunflower and rapeseed. The designated area for crop modelling was 1,282,000 ha within 55,100 MePAR blocks, which was considered representative for Hungary.

\subsection{Meteorological Data FORESEE}

The Open Database for Climate Change-Related Impact Studies in Central Europe (FORESEE) is a sophisticated, open access meteorological database that covers the period from 1951-2100 and contains observed and projected daily maximum/minimum temperatures and precipitation for Central Europe.

For the 1951-2018 period, FORESEE v3.1 provides interpolated meteorological fields based on observations, while for the 2018-2100 period, ten bias corrected regional climate model (RCM) results are available based on the projections created and disseminated within the framework of the ENSEMBLES FP6 project using the A1B emission scenario. The FORESEE is a simple database containing gridded daily meteorological data based on a state-of-the-art bias correction method for regional climate projections [21].

In this work, the daily global radiation, minimum and maximum temperature, and precipitation were used.

\subsection{Digital Soil Maps}

The Digital, Optimized, Soil Related Maps and Information (DOSoReMI.hu) initiative aims to renew the national soil spatial infrastructure in Hungary. Within the framework of DOSoReMI.hu, different soil property, soil type, and certain primary functional soil maps were compiled using up-to date digital soil mapping techniques incorporating geostatistical, machine learning, and Geographic Information System (GIS) tools. The soil property maps were compiled partly according to GlobalSoilMap.net specifications, partly by slightly or more strictly changing some of their predefined parameters (depth intervals, pixel size, property etc.) according to the specific requirements of the final product. The maps are published on the www.dosoremi.hu website, and the results were also elaborated by creating a specific WMS environment [22].

In the present research, we applied nationwide organic matter, clay, silt, and sand content maps, as well as USDA texture class maps from the DOSoReMI.hu database as input parameters for the $4 \mathrm{M}$ model. The maps were $100 \mathrm{~m} \times 100 \mathrm{~m}$ per pixel resolution for the following four depths: 0-30 cm, 30-60 cm, 60-100 cm, and 100-200 cm.

The 3D Soil Hydraulic Database of Europe (EU-SoilHydroGrids ver1.0) [23,24] provides information on the most essential soil hydraulic properties at $250 \mathrm{~m}$ resolution at seven soil depths up to $2 \mathrm{~m}$ with full European coverage. EU-SoilHydroGrids is a consistent spatial soil hydraulic database compiled based on SoilGrids250m [25] and $1 \mathrm{~km}$ datasets and pedotransfer functions trained on the European Hydropedological Data Inventory. The database contains maps on saturated water content, water content at field capacity and wilting point, saturated hydraulic conductivity, and Mualem-van Genuchten parame- 
ters for the description of the moisture retention and unsaturated hydraulic conductivity curves.

As input parameters for the $4 \mathrm{M}$ model, the following was used from EU-SoilHydroGrids: saturated water content $(\mathrm{pF}=0)$, water content at field capacity $(\mathrm{pF}=2.5)$, and wilting point $(\mathrm{pF}=4.2)$. In order to fit the requirements of the model, we limited the data to the territory of Hungary and converted the available information regarding the seven soil depths $(0 \mathrm{~cm}, 5 \mathrm{~cm}, 15 \mathrm{~cm}, 30 \mathrm{~cm}, 60 \mathrm{~cm}, 100 \mathrm{~cm}$, and $200 \mathrm{~cm})$ to $0-30-\mathrm{cm}, 30-60-\mathrm{cm}$, 60-100-cm, and 100-200-cm depth intervals.

The $4 \mathrm{M}$ model requires data on the bulk density of the soil. As there is currently no available bulk density map for Hungary in the DOSoReMI.hu database, we calculated bulk density values from the clay, sand, and organic matter content of soil according to a method described by Rawls [26].

According to the input data requirements of the $4 \mathrm{M}$ model, the soil properties were assigned to MePAR blocks from the spatial soil information detailed above. In cases of continuous variables, the block mean was calculated. As for soil properties (USDA texture classes), the dominant class was selected for each block. Furthermore, a FORESEE ID was assigned to each MePAR block.

We aggregated the data from the Nitrate Database (refers to parcels) for MePAR blocks. From data for the year 2016, we took in account only those crops which occupied the largest area. The fertilized area was computed from the sum of the area of the dominant crop, while areas dedicated to other crops were omitted.

\subsection{M Crop Model}

The computations of the $4 \mathrm{M}$ daily step, deterministic model are determined by the numerical characteristics (defined by input parameters) of the atmosphere-soil-plant system. Those input data describe the physical, chemical, and biological profile of the system. It is also necessary to set the initial, boundary, and constraint conditions in the input file of the model. The following parameters determine the model functions: development, growth, and senescence of plants, as well as the heat, water, and nutrient balance of the soil [20].

The initial conditions are the measured system variables at the beginning of the simulation run, such as the water or nutrient content of the soil. The boundary conditions are primarily the daily meteorological data, such as global radiation, temperature, and precipitation. The constraint conditions cover the numerical agro-management expressions, e.g., data about planting, harvest, fertilization, or irrigation.

Phenological development is based upon the cumulative thermal time. The daily photosynthesis rate is calculated using a Beer-Lambert law based equation. The produced mass is divided into the major parts (root, stem, leaf and yield) of the plant. The partitioning ratios change with the phenological stages. Matter allocated to the leaves is converted to area by multiplying the mass with the specific leaf area. The age of every leaf area portion that is added to the total area in a day is kept on record. If the age of a portion exceeds the value of the "lifespan of leaves" parameter it "dies", i.e., it ceases to take part in photosynthesis. The aging of leaves is accelerated by abiotic stress.

Root expansion depends on the daily thermal time and the minima of the water and nitrogen stress factors.

The water balance module calculates the following elements: runoff, evaporation, transpiration, and the volume of water percolating both downward and upward. The temperature of the soil layers is calculated according to the depth, taking into account that the upper soil layers absorb energy and the heat needs time to reach the lower layers. The extent of the delay and the decrease depend upon the average moisture content and the average bulk density of the topsoil.

The soil organic matter submodel includes three soil organic matter (SOM) pools (active, slow, and passive) with different potential decomposition rates, above and belowground crop residue pools, and a surface microbial pool, which is associated with decomposing surface residue. The decomposition of both plant residues and SOM is 
assumed to be microbially mediated, with an associated loss of $\mathrm{CO}_{2}$ due to microbial respiration.

Each pool is characterized by different maximum decomposition rates, which are reduced by multiplicative functions of soil moisture and soil temperature. The nutrient submodel uses simple equations to represent $\mathrm{N}$ inputs and outputs attributed to atmospheric deposition, fertilization, mineralization, nitrification, immobilization, denitrification, plant uptake, and nitrate leaching.

In this study, the $4 \mathrm{M}$ model simulated the yields of five principal crops (winter wheat, barley, maize, sunflower, and rapeseed) based on input parameters, $\mathrm{N}$ uptake by plants, nutrient balances, and amount of $\mathrm{NO}_{3}-\mathrm{N}$ leached under the $0-90 \mathrm{~cm}$ soil depth.

\subsection{Establishing Standard Nutrient Replenishment Technologies}

The Nitrate database contains the amounts of applied manure and mineral fertilizer expressed in active $\mathrm{N}$ - ingredients, while the dates of fertilizer application and distribution rates in cases of multiple applications are missing/absent. In contrast, $4 \mathrm{M}$ requires input regarding fertilizer application and meteorological factors with a daily step. To fulfill the model's input requirements, the standard dates of fertilizing were defined for the five principal crops based on real fertilizing dates (for the autumn and spring seasons as well) contained in the Nitrate database. The nitrogen distribution rates (in percent) per crop species were estimated and simulated based on the total applied amount of $\mathrm{N}$ $\left(\mathrm{kg} \mathrm{ha}^{-1}\right)$. To estimate the nitrogen distribution rates, real values from the Soil Degradation Information System (TDR) database were taken into account (Table 2), which, given its complete national coverage, represents roughly 2000 plots [27-29].

Table 2. Estimated date of $\mathrm{N}$ application depending on crops and doses. Methodology derived from the TDR database.

\begin{tabular}{|c|c|c|c|c|c|c|}
\hline & $1 \times$ Fertilized & $\%$ & $2 \times$ Fertilized & $\%$ & $3 \times$ Fertilized & $\%$ \\
\hline \multirow{4}{*}{ Winter wheat } & \multicolumn{2}{|c|}{$\mathrm{N}<50 \mathrm{~kg} \mathrm{ha}^{-1}$} & \multicolumn{2}{|c|}{$50 \mathrm{~kg} \mathrm{ha}^{-1}<\mathrm{N}<100 \mathrm{~kg} \mathrm{ha}^{-1}$} & \multicolumn{2}{|c|}{$\mathrm{N}>100 \mathrm{~kg} \mathrm{ha}^{-1}$} \\
\hline & 15th March & 100 & 5th October & 50 & 5th October & 25 \\
\hline & & & 1st April & 50 & 15th March & 40 \\
\hline & & & & & 15th April & 35 \\
\hline \multirow{4}{*}{ Winter barley } & \multicolumn{2}{|c|}{$\mathrm{N}<50 \mathrm{~kg} \mathrm{ha}^{-1}$} & \multicolumn{2}{|c|}{$50 \mathrm{~kg} \mathrm{ha}^{-1}<\mathrm{N}<80 \mathrm{~kg} \mathrm{ha}^{-1}$} & \multicolumn{2}{|c|}{$\mathrm{N}>80 \mathrm{~kg} \mathrm{ha}^{-1}$} \\
\hline & 15th March & 100 & 15th September & 60 & 15th September & 30 \\
\hline & & & 15th March & 40 & 5th March & 30 \\
\hline & & & & & 1st April & 40 \\
\hline \multirow{4}{*}{ Rapeseed } & \multicolumn{2}{|c|}{$\mathrm{N}<70 \mathrm{~kg} \mathrm{ha}^{-1}$} & \multicolumn{2}{|c|}{$70 \mathrm{~kg} \mathrm{ha}^{-1}<\mathrm{N}<110 \mathrm{~kg} \mathrm{ha}^{-1}$} & \multicolumn{2}{|c|}{$\mathrm{N}>110 \mathrm{~kg} \mathrm{ha}^{-1}$} \\
\hline & 15th March & 100 & 1st September & 40 & 1st September & 20 \\
\hline & & & 15th March & 60 & 5th March & 50 \\
\hline & & & & & 1st April & 30 \\
\hline \multirow{4}{*}{ Maize } & \multicolumn{2}{|c|}{$\mathrm{N}<80 \mathrm{~kg} \mathrm{ha}^{-1}$} & \multicolumn{2}{|c|}{$80 \mathrm{~kg} \mathrm{ha}^{-1}<\mathrm{N}<120 \mathrm{~kg} \mathrm{ha}^{-1}$} & \multicolumn{2}{|c|}{$\mathrm{N}>120 \mathrm{~kg} \mathrm{ha}^{-1}$} \\
\hline & 10th April & 100 & 10th April & 50 & 15th October & 20 \\
\hline & & & 10th May & 50 & 10th April & 40 \\
\hline & & & & & 10th May & 40 \\
\hline \multirow{3}{*}{ Sunflower } & \multicolumn{2}{|c|}{$\mathrm{N}<50 \mathrm{~kg} \mathrm{ha}^{-1}$} & \multicolumn{2}{|c|}{$50 \mathrm{~kg} \mathrm{ha}^{-1}<\mathrm{N}$} & & \\
\hline & 20th April & 100 & 10th October & 30 & & \\
\hline & & & 20th April & 70 & & \\
\hline
\end{tabular}

\subsection{Initial Soil Nitrate-N Content Data}

In order to use $4 \mathrm{M}$, information regarding the initial nitrate- $\mathrm{N}$ content in the $0-30$, 30-60, 60-90 cm soil profiles was required. These data, derived from the TDR database, averaged the initial nitrate- $\mathrm{N}$ content at 0-30, 30-60, 60-90, and 100-120 cm depths, depending on the soil physical properties (Table 3) [27-29]. 
Table 3. Average nitrate content $\left(\mathrm{mg} \mathrm{kg}^{-1}\right)$ estimation related to soil physical properties in the Nitrate database based on the TDR database.

\begin{tabular}{cccc}
\hline \multirow{2}{*}{ Soil Texture } & \multicolumn{3}{c}{ Average Nitrate Content $\mathbf{( m g ~ k g - \mathbf { 1 } )}$} \\
\cline { 2 - 4 } & $\mathbf{0 - 3 0} \mathbf{~ c m}$ & $\mathbf{3 0 - 6 0 ~} \mathbf{~ m ~}$ & $\mathbf{6 0 - 9 0 ~} \mathbf{~ m ~}$ \\
\hline sand & 16.9 & 10.0 & 4.1 \\
\hline sandy loam & 18.7 & 10.4 & 4.9 \\
\hline loam & 20.4 & 10.8 & 5.8 \\
\hline clay loam & 22.9 & 11.6 & 6.2 \\
\hline clay loam & 25.5 & 12.5 & 6.6 \\
\hline
\end{tabular}

\subsection{Software}

The Hungarian Nitrate Database was set up in Microsoft Access. Data verifying was done using Microsoft Excel. GIS queries and analyses, as well as spatial visualization of the data and the results of model 4M, were carried out using the ESRI ArcGIS 10.6 software.

\section{Results}

\subsection{The Amount of Total Nitrogen Applied to Crops (Hungarian Nitrate Database)}

The sum of the utilized proportion of organic $\mathrm{N}$ plus the total amount of mineral $\mathrm{N}$ fertilizer applied to the parcels of HND is shown on the Figure 1. The proportion of organic $\mathrm{N}$ utilized in the first year is specified according to Appendix 2 of 59/2008. FVM Decree. It was 0.4 for farmyard manure, and 0.5 for slurry. On the map, the sum of the utilized proportion of organic $\mathrm{N}$ plus the total amount of mineral $\mathrm{N}$ fertilizer is shown. The amounts of total $\mathrm{N}$ applied were highest in the west-southwest part of the country, as well as in the of Hajdúság Loess plateau, and lowest in the middle and north-east regions.

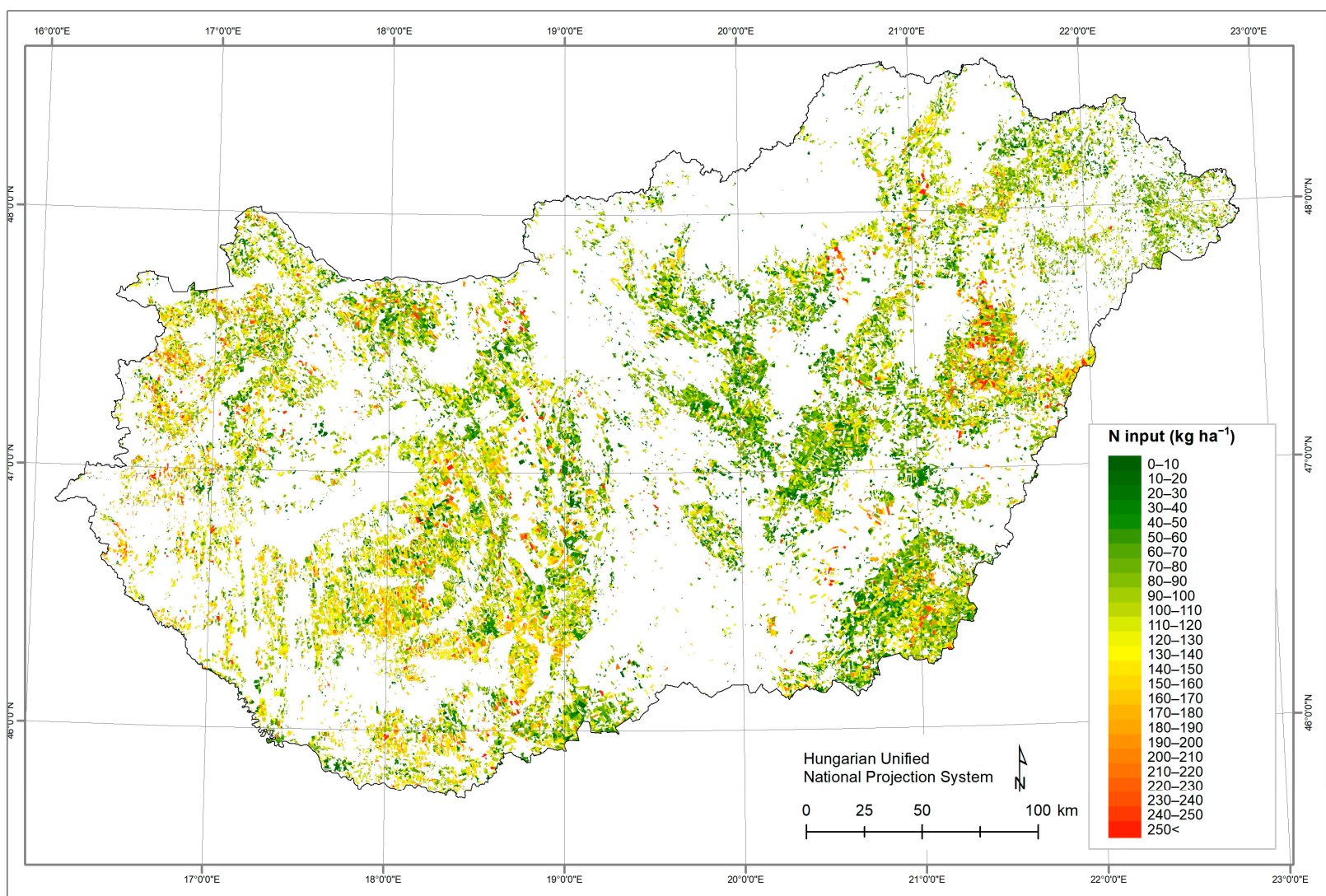

Figure 1. Amount of applied organic and inorganic nitrogen $\left(\mathrm{kg} \mathrm{ha}^{-1}\right)$; Hungarian Nitrate Database, 2016. 
The average amount of applied $\mathrm{N}$ was $96 \mathrm{~kg} \mathrm{ha}^{-1}$, comprising $15 \mathrm{~kg} \mathrm{~N}$ in the form of organic manure and $81 \mathrm{~kg}$ in the form of fertilizer. The distribution of $\mathrm{N}$ doses was as follows: $0-100 \mathrm{~kg} \mathrm{ha}^{-1}$ range: $57 \%$; $100-200 \mathrm{~kg} \mathrm{ha}^{-1}$ range: $40 \% ; 200-300 \mathrm{~kg} \mathrm{ha}^{-1}$ range: $3 \%$, as shown in Figure 1.

Based on an examination of the $\mathrm{N}$ application data, it was found that smaller farms (which are widely present in Hungarian agriculture) carry out more extensive fertilization practices. However, the rate of doses can only be assessed with knowledge of the cultivated plants and their $\mathrm{N}$ uptake.

\subsection{Determination of Crop N Uptake}

Using the input data, the $4 \mathrm{M}$ model estimated the yields, the $\mathrm{N}$ uptake of the five major crops (winter wheat, maize, barley, sunflower, and rapeseed), as well as the amount of $\mathrm{NO}_{3}-\mathrm{N}$ leached at a $0-90 \mathrm{~cm}$ soil depth. The crop $\mathrm{N}$ uptake $\left(\mathrm{kg} \mathrm{ha}^{-1}\right)$ can be observed for the area represented by the Hungarian Nitrate Database on the Figure 2.

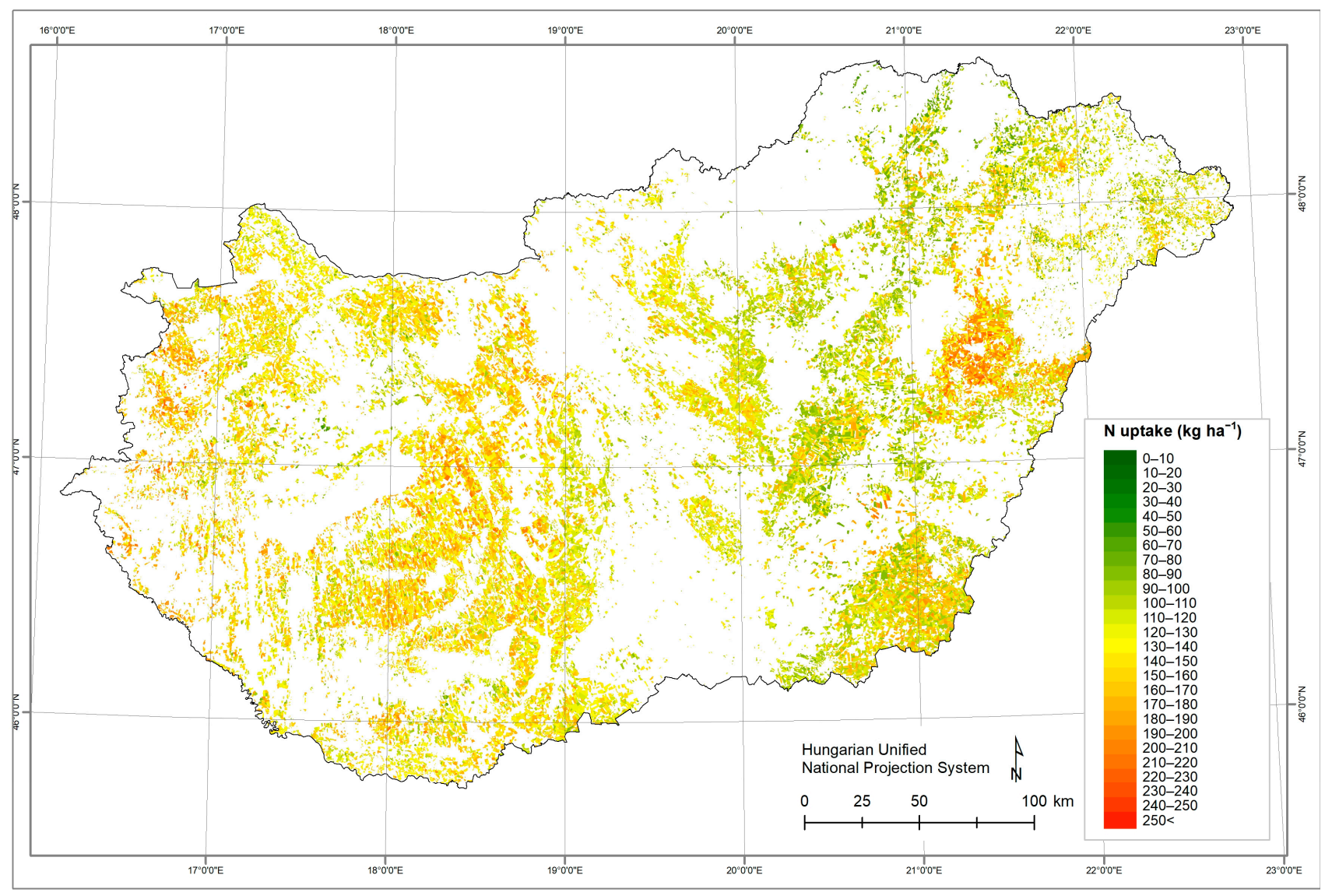

Figure 2. Amounts of crop $\mathrm{N}$ uptake $\left(\mathrm{kg} \mathrm{ha}^{-1}\right)$, 2016. Estimated using the $4 \mathrm{M}$ model.

Both estimations, i.e., based on either the Hungarian Nitrate Database or the $4 \mathrm{M}$ model results, showed negative $\mathrm{N}$ balances at a country scale, i.e., average $-39 \mathrm{~kg} \mathrm{~N}$ per hectare. This was confirmed by the differences in the applied $\mathrm{N}$ dose and $\mathrm{N}$ uptake distributions: the applied $\mathrm{N}\left(\mathrm{N}_{\text {inp }}\right)$ fell mostly within the $0-100 \mathrm{~kg} \mathrm{ha}^{-1}$ range, while the $\mathrm{N}$ uptake $\left(\mathrm{N}_{\text {upt }}\right)$ fell within the $100-200 \mathrm{~kg} / \mathrm{ha}$ range. Comparing the ratios of total applied $\mathrm{N}\left(\mathrm{N}_{\mathrm{inp}}\right)$ and $\mathrm{N}$ uptake $\left(\mathrm{N}_{\text {upt }}\right)$, we get the following:

- in the range of $0-100 \mathrm{~kg} \mathrm{ha}^{-1}: \mathrm{N}_{\text {inp }}$ is $57 \%$ and $\mathrm{N}_{\text {upt }}$ is $16 \%$;

- in the range of $100-200 \mathrm{~kg} \mathrm{ha}^{-1}: \mathrm{N}_{\text {inp }}$ is $40 \%$ and $\mathrm{N}_{\text {upt }}$ is $82 \%$;

- in the range above $200 \mathrm{~kg} \mathrm{ha}^{-1}: \mathrm{N}_{\text {inp }}$ is only $3 \%$ and $\mathrm{N}_{\text {upt }}$ is only $2 \%$. 
Due to the fact that 2016 was a particularly wet year, providing high yields, crop $\mathrm{N}$ uptake was also higher than usual. Comparing the two maps, it can be observed that in most areas covered by the nitrate load database, there were negative $\mathrm{N}$ balances. Since the $4 \mathrm{M}$ model estimated the total $\mathrm{N}$ amount of the above-ground parts of plants for areas with byproducts remaining in the field, the $\mathrm{N}$ amounts taken up by the byproducts should not be taken into account at the outputs of the $\mathrm{N}$ balances. Even if these correction factors are taken into account, on the majority of the area included in the database, the $\mathrm{N}$ balances were presumed to be around zero $\mathrm{kg} \mathrm{ha}^{-1}$ or even negative.

It is definitely remarkable and proves the qualities of the $4 \mathrm{M}$ model that the crop $\mathrm{N}$ uptake map showed close correlation with the potential agro-productivity map of Hungary [30]. It is evident that higher plant $\mathrm{N}$-uptake is related to higher crop yields. Thus, the N-uptake map refers more or less to the national crop yield maps as well.

As such, the $4 \mathrm{M}$ model meets the requirement of being sensitive to differences in input data. Furthermore, it shows the achievable yield on a given field using a given set of agronomic interventions.

\subsection{Agronomic and Agro-Environmental Consequences of Shortening the Prohibition Time}

In the currently decree of 59/2008. (IV.29) FVM, the prohibition time is defined as the period from 31st October to 15thFebruary (D1). Besides this period, model runs were carried out for more reasonable periods, as defined by the authors: 15th November-15th February (D2), or 30th November-15th February (D3) (Table 4). The aim of running the $4 \mathrm{M}$ model with the different scenarios was to estimate whether changing to less strict prohibition intervals would cause a significant increase in nitrate leaching.

Table 4. N application timing of the D3 scenario Nitrogen doses applied in autumn were shifted by one month.

\begin{tabular}{|c|c|c|c|c|c|c|}
\hline & $1 \times$ Fertilized & $\%$ & $2 \times$ Fertilized & $\%$ & $3 \times$ Fertilized & $\%$ \\
\hline \multirow{4}{*}{ Winter wheat } & \multicolumn{2}{|c|}{$\mathrm{N}<50 \mathrm{~kg} \mathrm{ha}^{-1}$} & \multicolumn{2}{|c|}{$50 \mathrm{~kg} \mathrm{ha}^{-1}<\mathrm{N}<100 \mathrm{~kg} \mathrm{ha}^{-1}$} & \multicolumn{2}{|c|}{$\mathrm{N}>100 \mathrm{~kg} \mathrm{ha}^{-1}$} \\
\hline & 15th March & 100 & 5th November * & 50 & 5th November * & 25 \\
\hline & & & 1st April & 50 & 15th March & 40 \\
\hline & & & & & 15th April & 35 \\
\hline \multirow{4}{*}{ Winter barley } & \multicolumn{2}{|c|}{$\mathrm{N}<50 \mathrm{~kg} \mathrm{ha}^{-1}$} & \multicolumn{2}{|c|}{$50 \mathrm{~kg} \mathrm{ha}^{-1}<\mathrm{N}<80 \mathrm{~kg} \mathrm{ha}^{-1}$} & \multicolumn{2}{|c|}{$\mathrm{N}>80 \mathrm{~kg} \mathrm{ha}^{-1}$} \\
\hline & 15th March & 100 & 15th October & 60 & 15th October & 30 \\
\hline & & & 15th March & 40 & 5th March & 30 \\
\hline & & & & & 1st April & 40 \\
\hline \multirow{4}{*}{ Rapeseed } & \multicolumn{2}{|c|}{$\mathrm{N}<70 \mathrm{~kg} \mathrm{ha}^{-1}$} & \multicolumn{2}{|c|}{$70 \mathrm{~kg} \mathrm{ha}^{-1}<\mathrm{N}<110 \mathrm{~kg} \mathrm{ha}^{-1}$} & \multicolumn{2}{|c|}{$\mathrm{N}>110 \mathrm{~kg} \mathrm{ha}^{-1}$} \\
\hline & 15th March & 100 & 1st October & 40 & 1st October & 20 \\
\hline & & & 15th March & 60 & 5th March & 50 \\
\hline & & & & & 1st April & 30 \\
\hline \multirow{4}{*}{ Maize } & \multicolumn{2}{|c|}{$\mathrm{N}<80 \mathrm{~kg} \mathrm{ha}^{-1}$} & \multicolumn{2}{|c|}{$80 \mathrm{~kg} \mathrm{ha}^{-1}<\mathrm{N}<120 \mathrm{~kg} \mathrm{ha}^{-1}$} & \multicolumn{2}{|c|}{$\mathrm{N}>120 \mathrm{~kg} \mathrm{ha}^{-1}$} \\
\hline & 10th April & 100 & 10th April & 50 & 15th November & 20 \\
\hline & & & 10th May & 50 & 10th April & 40 \\
\hline & & & & & 10th May & 40 \\
\hline \multirow{3}{*}{ Sunflower } & \multicolumn{2}{|c|}{$\mathrm{N}<50 \mathrm{~kg} \mathrm{ha}^{-1}$} & \multicolumn{2}{|c|}{$50 \mathrm{~kg} \mathrm{ha}^{-1}<\mathrm{N}$} & & \\
\hline & 20th April & 100 & 10th November & 30 & & \\
\hline & & & 20th April & 70 & & \\
\hline
\end{tabular}

* The shifted application date falls within the current prohibition period.

Compared to the current regulations, the modified application date falls within November for $40 \%$ of the blocks in the case of the D3 scenario (Table 5). If winter barley or rapeseed is produced, the modified application date does not affect the current prohibition 
period. In the case of intensive winter wheat cultivation, the modified fertilization date is in November. Producing spring sown plant such as maize and sunflower only, the amount of nitrogen can be released in autumn, which is required to decompose plant residues; this means November fertilization according to the modified application timing.

Table 5. The quantitative characteristics of areas affected by fertilization in November in the case of modified application.

\begin{tabular}{ccc}
\hline & Number of Blocks & Area (ha) \\
\hline Winter wheat & 8468 & 214,896 \\
Maize & 6765 & 166,966 \\
Sunflower & 7022 & 139,259 \\
\hline Total & 22,255 & 521,121 \\
\hline Proportion to modeling & $\mathbf{4 0 . 3 9 \%}$ & $\mathbf{4 0 . 6 3 \%}$ \\
\hline
\end{tabular}

Changing the starting date of the prohibition interval from 31st October to 15th November or to 30th November (and thus, shortening the prohibition interval) did not cause perceptible differences in the amount of $\mathrm{N}$ leached at $0-90 \mathrm{~cm}$ depth. Similarly, there were almost no differences in plant N-uptake and nitrogen balances. After running the $4 \mathrm{M}$ model with the two extreme scenarios (with starting dates of 31st October (D1) and 30th November (D3)), the differences in the amount of $\mathrm{N}$ leached at 0-90 depth were calculated, and are shown in Figure 3.

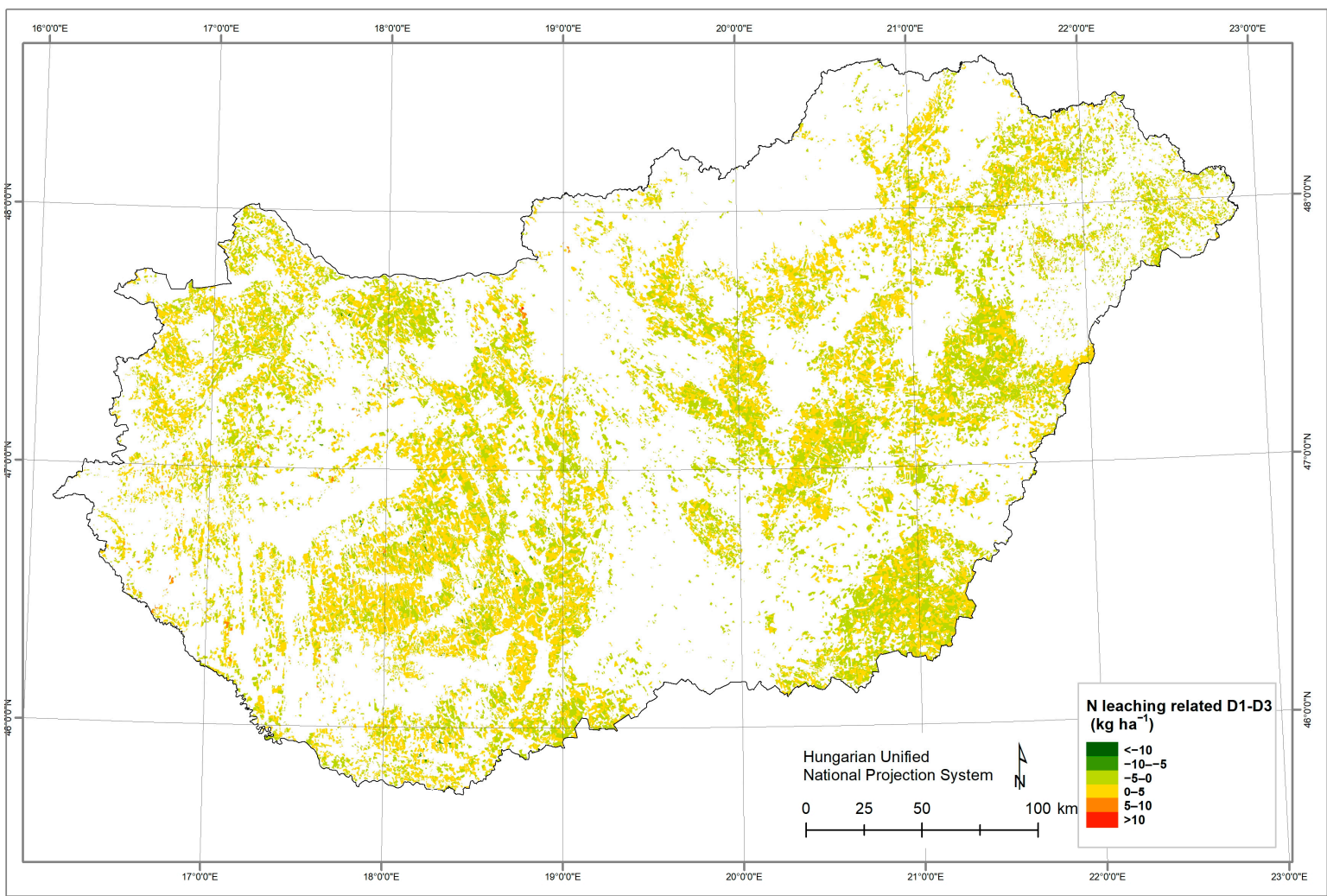

Figure 3. Differences in the amount of $\mathrm{N}$ leached at depths of $0-90 \mathrm{~cm}$ related to the $\mathrm{D} 1$ prohibition interval (31st October15th February) and D3 prohibition interval (30th November-15th February), 2016. Estimated using the 4M model.

As indicated in Figure 3, 99.2\% of the differences between scenarios D1 and D3 were situated in the -5 and $+5 \mathrm{~kg} \mathrm{ha}^{-1} \mathrm{~N}$ leaching category; consequently, no substantial changes were caused by shortening the prohibition period by 1 month. 


\section{Discussion}

There may be several reasons for the minimal differences in $\mathrm{N}$ leaching observed between the two scenarios. In the case of later fertilization in autumn, less precipitation occurs, causing a moderate change in the leaching of nutrients. Based on the data of the Hungarian Meteorological Service, the average precipitation in November is about $50 \mathrm{~mm}$ in Hungary (Figure 4) [31]. Therefore, in the case of fertilization at the end of November until the end of the winter prohibition period (December, January, first part of February), only $85 \mathrm{~mm}$ rain is to be expected. This small amount is not enough to leach out $\mathrm{NO}_{3}-\mathrm{N}$ under the root zone, so in spring, as the growing season starts, plants can easily take up this nutrient.

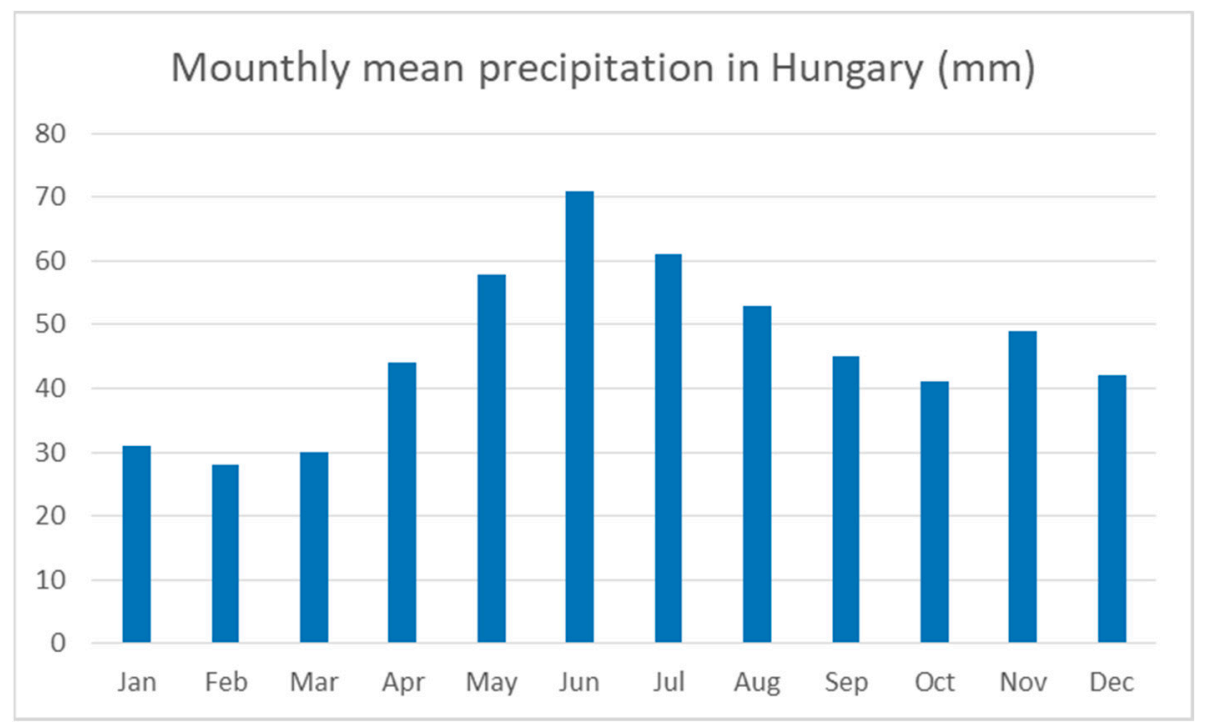

Figure 4. Average monthly precipitation (mm) of Hungary based on 1971-2000.

In order to slow the rate of global warming and diminish the adverse effects of climate change, reducing $\mathrm{CO}_{2}$ levels in air was set as a priority in EU climate policy. To reach this goal under a community arrangement, standards of emission reductions were fixed. EU countries shall reduce their greenhouse gases (GHG) emissions by a certain percent over a definite time period compared to the 1990 base year levels. Additionally, strict $\mathrm{CO}_{2}$ emissions quotas were set [32].

As issues related to global warming were acknowledged at the EU level, reviewing their policy on defining the length of the winter fertilization prohibition period in the Nitrates Directive would be a logical progress.

The period when the topsoil is frozen in Hungary and in other countries has decreased significantly. Before or after the current prohibition period, frozen topsoil cannot be expected to enhance the leaching of nitrogen fertilizer loads.

To estimate the nitrate leaching exposure, i.e., as minor, moderate, or high, the DirectorateGeneral for the Environment (DG-ENV) and Task Force on Reactive Nitrogen (TFRN) defined 13 climate zones in the EU. Hungary belongs to the Pannonian (PAN) climate [33-36]. Within this climate region (and also in two other groups), the amount of precipitation never exceeds the amount of evapotranspiration, so the risk of nitrate leaching is minimal.

This study represents a first look at the environmental effect of altering the prohibition period. Effects over longer periods on the amount of N leached related to the D1 and D3 prohibition interval can be estimated by $4 \mathrm{M}$ runs with different weather scenarios using same Hungarian Nitrate Database from 2016.

\section{Conclusions}

Confirming our hypothesis, it was found that shortening the prohibition period by changing the start date from 31st October to 15th November or to 30th November did not 
result in significant differences either in crop $\mathrm{N}$ uptake or in the amount of $\mathrm{NO}_{3}-\mathrm{N}$ leached under the root zone $(0-90 \mathrm{~cm})$.

The results of $4 \mathrm{M}$ model simulations deferring the starting date by one month from 31st October to 30th November showed no increase in agro-environmental risk (that is, increased amount of $\mathrm{NO}_{3}-\mathrm{N}$ leached under 0-90 cm soil depth or changes in nutrient balances). In accordance with these results, a shortening of the prohibition period seems to be possible, but results from just one year should be viewed with caution, since crop $\mathrm{N}$ uptake may vary, as may environmental variables such as the rainfall in autumn or winter. Further application of the $4 \mathrm{M}$ model with different weather scenarios (wet, average, dry) for the same year (2016) database, or using databases of other years (2017, 2018, etc.), are needed to determine whether the modification of the prohibition period will significantly affect the amount of nitrate leached.

Author Contributions: Conceptualization, S.K., B.P., P.C., A.S.; methodology, S.K., B.P., G.S., P.C., M.M., J.S., N.F., L.P., A.L., A.S.; software, G.S., N.F., L.P., A.L.; validation, S.K., B.P., P.C., A.S.; formal analysis, S.K., B.P., G.S., A.L.; investigation, B.P., P.C., A.S., M.M.; resources, N.F., L.P.; data curation, S.K., B.P., P.C., A.S.; writing-original draft preparation, S.K., B.P., P.C., A.S.; writing-review and editing, S.K., B.P., P.C., M.M., L.P., K.P., A.S.; visualization, A.L., M.M.; supervision, L.P., P.C.; project administration, S.K.; funding acquisition, S.K., B.P., L.P. All authors have read and agreed to the published version of the manuscript.

Funding: The work has been supported by the Hungarian Ministry of Agriculture (AGMF/61/2019) fundamentally. Our work has been supported by the National Research, Development and Innovation Office (NKFIH; Grant Nos. KH-126725 and K-131820) and by the Higher Education Institutional Excellence Programme (NKFIH-1150-6/2019) of the Hungarian Ministry of Innovation and Technology, within the framework of the 4th thematic Programme of the University of Debrecen.

Institutional Review Board Statement: Not applicable.

Informed Consent Statement: Not applicable.

Data Availability Statement: 3rd Party Data: Restrictions apply to the availability of these data. Hungarian Nitrate Database was obtained from National Food Chain Safety Office (NFCSO) and are available from the authors with the permission of NFCSO.

Conflicts of Interest: The authors declare no conflict of interest. The funders had no role in the design of the study; in the collection, analyses, or interpretation of data; in the writing of the manuscript, or in the decision to publish the results.

\section{References}

1. Németh, T. Organic Matter and Nitrogen Content of Soils; MTA TAKI: Budapest, Hungary, 1996; 382p, ISBN 963-0476-73-8.

2. Van Grinsven, H.J.M.; Bouwman, L.; Cassman, K.G.; van Es, H.M.; McCrackin, L.; Beusen, A.H.W. Losses of Ammonia and Nitrate from Agriculture and Their Effect on Nitrogen Recovery in the European Union and the United States between 1900 and 2050. J. Environ. Qual. 2015, 44, 356-369. [CrossRef] [PubMed]

3. EU Commission. Directive 91/676/EEC. Council Directive of 12 December 1991 Concerning the Protection of Waters Against Pollution Caused by Nitrates from Agricultural Sources. Official Journal of European Community L375: 1-8. Available online: https: / / eur-lex.europa.eu/legal-content/EN/ALL/?uri=CELEX\%3A31991L0676 (accessed on 19 October 2020).

4. EU. The EU Nitrates Directive. Retrieved 19 November, 2018. Available online: http://ec.europa.eu/environment/pubs/pdf/ factsheets/nitrates.pdf (accessed on 19 October 2020).

5. EU Commission. Report from the Commission to the Council and the European Parliament on the Implementation of Council Directive 91/676/EEC Concerning the Protection of Waters against pollution caused by Nitrates from Agricultural Sources Based on Member State Reports for the Period 2008-2011. 2013. Available online: https:/ / eur-lex.europa.eu/legal-content/en/TXT/ ?uri=CELEX:52013DC0683 (accessed on 19 October 2020).

6. EEA. Nutrients in Freshwater. Published 3 December, 2019. Available online: www.eea.europa.eu/data-and-maps/indicators/ nutrients-in-freshwater/nutrients-in-freshwater-assessment-published-9 (accessed on 19 October 2020).

7. Hajas, J.; Rázsó, I. Agriculture in Numbers; Mezőgazdasági Kiadó: Budapest, Hungary, 1969.

8. Csathó, P.; Radimszky, L. Sustainable agricultural NP turnover in the EU 27 countries. In Organic Fertilization, Soil Quality and Human Health. Sustainable Agricultural Reviews 9; Lichtfouse, E., Ed.; Springer: Dordrecht, The Netherlands; Heidelberg, Germany; New York, NY, USA; London, UK, 2012; pp. 161-186, ISBN 978-94-00-6. [CrossRef]

9. Berényi Üveges, K.; Csányi, G.; Keszthelyi, K.; Kujáni, K.O.; Szabados, I.; Sztahura, E.; Várszegi, G. NITRÁT. Gazdálkodói Kézikönyv; NAK: Budapest, Hungary, 2015; ISBN 978-615-5307-18-8. 
10. Csathó, P.; Radimszky, L. Two worlds within EU27: Sharp contrasts in organic and mineral NP use, NP balances and soil P status. Widening and deepening gap between Western and Central Europe. Commun. Soil Sci. Plant Anal. 2009, 40, 999-1019. [CrossRef]

11. Fodor, N.; Csathó, P.; Árendás, T.; Radimszky, L.; Németh, T. Crop nutrient status and NPK balances, obtained in the field trials, evaluating of different fertilizer recommendation systems on various soils and crops in Hungary. Commun. Soil Sci. Plant Anal. 2013, 44, 996-1010. [CrossRef]

12. Schils, R.; Olesen, J.E.; Kersebaum, K.-C.; Rijk, B.; Oberforster, M.; Kalyada, V.; Khitrykau, M.; Gobin, A.; Kirchev, H.; Manolova, V.; et al. Cereal yield gaps across Europe. Eur. J. Agron. 2018, 101, 109-120. [CrossRef]

13. Ministry of Agriculture and Rural Development Decree on the Detailed Rules of the Action Program for the Protection of Waters Against Nitrate Pollution of Agricultural Origin, as well as about Data Provision and Registration. Available online: Net.jogtar.hu/jogszabaly?docid=a0800059.fvm (accessed on 19 October 2020). (In Hungarian).

14. Tzilivakis, J.; Green, A.; Warner, D.J.; Lewis, K.A. Identification of Approaches and Measures in Action Prorammes under Directive 91/676/EEC. Final Report: Report Prepared for Directorate-General Environment, European Commission, for project ENV.D.1/SER/2018/0017 by the Agriculture and Environment Research Unit (AERU), University of Hertfordshire, UK. 2020. Available online: https://ec.europa.eu/environment/water/water-nitrates/pdf/NAPINFO\%20report.pdf (accessed on 19 October 2020).

15. 27/2006. (II. 7.) Government Decree on the Protection of Waters Against Pollution Caused by Nitrates from Agricultural Sources. Available online: Net.jogtar.hu/jogszabaly?docid=a0600027.kor (accessed on 19 October 2020). (In Hungarian)

16. Agricultural Parcel Identification System. Available online: www.mepar.hu/ (accessed on 19 October 2020). (In Hungarian)

17. 43/2007. (VI. 1.) Ministry of Agriculture and Rural Development Decree on the Publication of Nitrate-Sensitive Areas at the Level of Blocks According to MePAR. (in Hungarian) Available online: Net.jogtar.hu/jogszabaly?docid=a0700043.fvm (accessed on 19 October 2020).

18. Csathó, P.; Árendás, T.; Fodor, N.; Németh, T. Evaluation of different fertilizer recommendation systems on various soils and crops in Hungary. Commun. Soil Sci. Plant Anal. 2009, 40, 1689-1711. [CrossRef]

19. Fodor, N.; Csathó, P.; Árendás, T.; Németh, T. New environment-friendly and cost-saving fertiliser recommendation system for supporting sustainable agriculture in Hungary and beyond. J. Cent. Eur. Agric. 2011, 12, 53-69. [CrossRef]

20. Fodor, N.; Pásztor, L.; Németh, T. Coupling the $4 \mathrm{M}$ crop model with national geo-databases for assessing the effects of climate change on agro-ecological characteristics of Hungary. Int. J. Digit. Earth 2014, 7, 391-410. [CrossRef]

21. Dobor, L.; Barcza, Z.; Hlásny, T.; Havasi, Á.; Horváth, F.; Ittzés, P.; Bartholy, J. Bridging the gap between climate models and impact studies: The FORESEE Database. Geosci. Data J. 2014, 2, 1-11. [CrossRef] [PubMed]

22. Pásztor, L.; Laborczi, A.; Takács, K.; Szatmári, G.; Bakacsi, Z.; Szabó, J.; Illés, G. DOSoReMI as the national implementation of GlobalSoilMap for the territory of Hungary. In GlobalSoilMap_Digital Soil Mapping from Country to Globe; Arrouays, D., Savin, I., Leenaars, J., McBratney, A.B., Eds.; CRC Press: London, UK, 2018; pp. 17-22.

23. Tóth, B.; Weynants, M.; Pásztor, L.; Hengl, T. 3D Soil Hydraulic Database of Europe at 250 m resolution. Hydrol. Process. 2017, 31, 2662-2666. [CrossRef]

24. 3D Soil Hydraulic Database of Europe at $250 \mathrm{~m}$ Resolution (EU-SoilHydroGrids ver 1.0). Available online: https: / / eusoilhydrogrids.rissac.hu (accessed on 19 October 2020).

25. Hengl, T.; Mendes de Jesus, J.; Heuvelink, G.B.M.; Ruiperez Gonzalez, M.; Kilibarda, M.; Blagotić, A.; Shangguan, W.; Wright, M.N.; Geng, X.; Bauer-Marschallinger, B.; et al. SoilGrids250m: Global gridded soil information based on machine learning. PLoS ONE 2017, 12, e0169748. [CrossRef] [PubMed]

26. Rawls, W.J. Estimating soil bulk density from particle size analysis and organic matter content. Soil Sci. 1983, 135, 123-125. [CrossRef]

27. Szabó, J.; Pirkó, B.; Szabóné Kele, G.; Havas, Á.; Podmaniczky, L.; Pásztor, L.; Dombos, M.; Bakacsi, Z.S.; László, P.; Koós, S.; et al. Az Országos Környezeti Információs Rendszer (OKIR) talajdegradációs alrendszerének (TDR) kialakítása. In Az elmélet és gyakorlat találkozása a térinformatikában III-Térinformatikai konferencia és szakkiállitás; Lóki, J., Ed.; Debreceni Egyetemi Kiadó: Debrecen, Hungary, 2012; p. 8, ISBN 978-963-318-218-5.

28. Development of Soil Degradation Subsystem (TDR) of the National Environmental Information System (OKIR). Available online: www.mta-taki.hu/hu/tdr (accessed on 19 October 2020).

29. Soil Degradation System (TDR). Available online: Okir-tdr.helion.hu/ (accessed on 19 October 2020). (In Hungarian)

30. Pásztor, L.; Laborczi, A.; Takács, K.; Szatmári, G.; Fodor, N.; Gábor, I.; Farkas-Iványi, K.; Bakacsi, Z.; Szabó, J. Compilation of functional soil maps for the support of spatial planning and land management in Hungary. In Soil Mapping and Process Modeling for Sustainable Land Use Management; Elsevier: Atlanta, GA, USA, 2017; pp. 293-317. [CrossRef]

31. Hungarian Meteorological Service: Precipitation Conditions of Hungary. Available online: https://www.met.hu/en/eghajlat/ magyarorszag_eghajlata/altalanos_eghajlati_jellemzes/csapadek/ (accessed on 19 October 2020).

32. Annual European Union Greenhouse gas Inventory 1990-2017 and Inventory Report 2019. Submission under the United Nations Framework Convention on Climate Change and the Kyoto Protocol. EEA Report No 6/2019. Available online: www.eea.europa.eu/publications / european-union-greenhouse-gas-inventory-2019 (accessed on 19 October 2020). 
33. Oenema, O. Principles of overall nitrogen management: Background document. In Towards Joined-Up Nitrogen Guidance for Air, Water and Climate Co-Benefits; Report from the Joint DG ENV \& TFRN Workshop: Brussels, Belgium, 2016; pp. 7-44. Available online: http:/ / www.clrtap-tfrn.org/content/joint-dg-env-tfrn-workshop-towards-joined-nitrogen-guidance-air-water-andclimate-co (accessed on 19 October 2020).

34. Metzger, M.J.; Bunce, R.G.H.; Jongman, R.H.G.; Mücher, C.A.; Watkins, J.W. A climatic stratification of the environment of Europe. Glob. Ecol. Biogeogr. 2005, 14, 549-563. [CrossRef]

35. Metzger, M.J. The Environmental Stratification of Europe; University of Edinburgh: Edinburgh, UK, 2018. [CrossRef]

36. Recommendations for establishing Action Programmes under Directive 91/676/EEC concerning the Protection of Waters against Pollution Caused by Nitrates from Agricultural Sources. Part D. Recommendations for Measures. 2011. Alterra, Wageningen-UR, Wageningen, 139p. Available online: op.europa.eu/s/orn8 (accessed on 19 October 2020). 